\title{
Norské drama 20. století slovem i tělem
}

\author{
Karolína Stehlíková
}

Ivo de Figueiredo. ord/kjøtt. Norsk scenedramatikk 1890-2000. Oslo: Cappelen Damm, 2014. 501 s.

Autor knihy, jejíž název v češtině zní slovo/ tělo. Norská scénická dramatika 1890-2000, není původem teatrolog ani literární historik. Jeho domovským oborem je historie a de Figueiredovy první knihy také čerpaly témata z norských dějin. Obrat nastal v roce 2002, kdy čerstvě oceněnému autorovi nabídlo nakladatelství Aschehoug takřka životní výzvu - zpracovat nový životopis Henrika Ibsena u př́ležitosti stého výročí úmrtí světově proslulého dramatika. Ivo de Figueiredo souhlasil, a tak se dostal k psaní o divadle. Dvoudílný životopis Henrika Ibsena vyšel v letech 2006 a 2007, český překlad jeho jednodílné verze s názvem Henrik Ibsen. Člověk a maska publikovalo nedávno nakladatelství Karolinum (viz recenze Barbary Gregorové uveřejněná v tomto čísle Theatralii). Nový životopis Henrika Ibsena sklidil mediální i odbornou pozornost, která stála v pozadí další práce „na zakázku“.

Profesní organizace Asociace norských dramatiků (Dramatikerforbundet) autora oslovila, aby u př́ležitosti 75. výročí její existence napsal knihu, která by podrobně pojednala norské drama napsané po Henriku Ibsenovi. Výsledkem je úctyhodná publikace o pěti stech stranách s bohatým fotografickým doprovodem, která zahrnuje norské drama napsané „pro scénu“ v letech 1890-2011 (proto také podtitul „Norská scénická dramatika“). Autor ze své pozornosti cíleně vynechává rozhlasovou a televizní dramatiku, dramatiku pro děti a mládež a víceméně pomíjí projektové divadlo, rozvíjející se v Norsku od 70. let 20. století.

Vezmeme-li v úvahu prostý fakt, že norská dramatika 20. století není až na několik drobných výjimek bohatá na autory a díla, která by byla známá také za hranicemi Norska, vnucuje se otázka, jak by asi vypadala podobná kniha o dramatice české, kdyby byla podobně koncipovaná.

Knihu otevírá kapitola nazvaná „Ibsenův stín“ a ukončuje kapitola „Fosseho světlo“, což automaticky sugeruje představu jezdce na stupnici kontrastu, který se z temna postupně posouvá k většímu jasu. Mohlo by se na první pohled zdát, že autor moderní vývoj norské dramatiky skutečně takto vidí. Mapuje dílo více i méně úspěšných Ibsenových kolegů, epigonů i jeho „popíračů “ až po dramatiky, jejichž tvorba se od té Ibsenovy liší jako den a noc, která nicméně svou opakovanou uváděností a překládaností dokazuje, že byl nalezen nový funkční model. Jenže cesta, kterou de Figueiredo sleduje, pochopitelně není úplně takto přímočará a navíc je pravda, jak poukázala Wenche Larsenová ve své polemice proslovené v podobě přednášky na univerzitě v Oslu, že díky postulovanému omezení na drama „pro scénu“ je ke všemu přiznaně osekaná o mnoho pozoruhodných odboček a možná tak sama zůstává v ibsenovském stínu. K tomu de Figueiredo namítá, že nějak svou práci ohraničit musel. Koneckonců zadání kni- 
hy vzešlo od organizace, která sdružuje lidi produkující text.

V kapitole „Ibsenův stín“ podrobil autor rozboru díla dramatiků, kteří byli Ibsenovi generační souputníci (Alexander L. Kielland, Amalie Skramová) či jen o něco mladší kolegové (Arne Garborg, Gunnar Heiberg). Již v tomto okamžiku přichází na rozdělení, kterého bude dále užívat v celé knize. Rozdělení na dramatiky pravé (pro něž je drama primárním žánrem a které v norské dramatice pokládá za zř́ídkavý jev) a dramatiky nepravé (kteří si k psaní dramatiky jen odskakují z jiných žánrů). Autor nedochází k nabízejícímu se závěru, že praví dramatici (věnující se dramatu většinovou šírí svého tvưrčího záběru) píší ty nejdůležitější a nejlepší hry. Ačkoli tomu tak je nejčastěji, tvrdí de Figueiredo, existují i výjimky potvrzující pravidlo. $\mathrm{V}$ této souvislosti jmenuje např. spisovatele Arne Garborga, autora jediné, ovšem dodnes fungující hry s názvem Učitel, nebo bytostného modernistického lyrika Sigbjørna Obstfeldera.

Mezi nepravé dramatiky patří podle de Figueireda i spisovatel Knut Hamsun, jeden z norských držitelů Nobelovy ceny za literaturu. V kapitole nazvané „Odpůrce divadla“ zkoumá de Figueiredo důvody, které stály za tím, že výsostný romanopisec napsal za svůj život šest divadelních her. Hamsun prorazil v době, kdy drama bylo důležitým žánrem a divadlo socio-kulturní arénou (nezanedbatelný byl i ekonomický přínos). Mladý Hamsun sice spáchal „otcovraždu“, když v 90. letech 19. století vyrazil na přednáškové turné, v němž veřejně tupil tehdejší ikony norské literatury s Henrikem Ibsenem v čele, na druhou stranu byl ale pozorným návštěvníkem divadla, příležitostným kritikem a souzněl se Strindbergo- vou představou formálně rozvolněného dramatu inspirovaného subjektivním prožitkem a nietzscheovskou filozofií duševního aristokratismu. Při pozorném čtení Hamsunovy trilogie Před branou královstvi, Hra života a Večerni červánky (1895-1897) - první dvě hry byly přeloženy do češtiny - nachází de Figueiredo paralely s hrdiny i tématy tehdejších Hamsunových románů a zkoumá, jak si přecitlivělí hrdinové nového romantismu vedou na scéně. Dochází k závěru, že nemožnost využívat - pro Hamsuna tolik typický - subtilní hlas vypravěče spolu s různorodými úhly náhledu na postavu zpo̊sobuje, že jeho dramatický styl je sice průzračnější, ale zjednodušující. Hamsun se tehdy prostě neodvážil zásadněji inovovat dramatickou formu, aby lépe odpovídala ustrojení jeho postav. Tomu se není co divit, zásadní symbolistická dramata světové dramatiky byla napsána až po roce 1900. Hamsun se o drama nicméně pokoušel i v novém století. Veršem napsal knižní drama Munken Vendt, v němž se nechal inspirovat pikareskní poutí Peera Gynta, při psaní další „pohádkové“ hry Královna Tamara zužitkoval svou cestu na Kavkaz a svou dramatickou dráhu ukončil dramatem ze současnosti Ve spárech života o stárnoucí kabaretní herečce. Byt’ dnes je Hamsunova dramatika téměř zcela zapomenutá, ve své době se těšila pozornosti avantgardních divadelníků. Zvláště Max Reinhardt uvedl mezi lety 1899 a 1929 s úspěchem několik Hamsunových dramat.

Pokud jsme se zastavili u nepravých dramatiků, nabízí se otázka, kteří jsou tedy ti nejzajímavější „praví“ norští dramatici po Ibsenovi. De Figueiredo sám vnímá jako nejinovativnější norské dramatiky 20. století (před Jonem Fossem) Nordahla Griega (1902-1943) a Jense Bjørneboa 
(1920-1976). Nordahl Grieg je dnes v Norsku vnímán především jako básník a intelektuál-hrdina (zahynul jako válečný korespondent za 2. světové války). Jeho báseň Mládeži, která byla zhudebněna, se nedávno opět stala aktuální v souvislosti s uctěním památky masakru politicky angažované mládeže v roce 2011. Nordahl Grieg je spornou postavou norského kulturního života. Jeho radikální politické názory (ve třicátých letech pobýval v Sovětském svazu, zúčastnil se Moskevských procesů a stal se př́ivržencem Stalina) nic nemění na faktu, že jeho tvorbu výrazně ovlivnilo setkání se sovětským avantgardním divadlem, konkrétně Mejercholdovým a Vachtangovovým. Jeho drama Naše čest a naše sila vznikalo v těsné spolupráci s uměleckým šéfem Národní scény v Bergenu Hansem Jacobem Nilsenem, který k jeho napsání Griega vyzval. Hra tematizující nemorální chování norských rejdařských společností za první světové války po své premiéře sklidila neočekávaný úspěch u publika i kritiky. Drama se vyznačuje stavbou poučenou filmovým střihem a kontrastními scénami, které se často proměňují v němé obrazy, včetně zcizujícího komentáře dění na scéně, jenž zajištovali herci v publiku. Griegova hra Porážka z roku 1937 o Pařížské komuně je pro změnu analýzou revoluční anatomie a zároveň komentářem ke španělské občanské válce (ovšem i k Moskevským procesům, jak rozkryli současní badatelé). Grieg tu přivádí na scénu 70 postav a předvádí nejkrvavější drama v historii norské dramatiky. Tato hra inspirovala Bertolta Brechta k napsání opoziční hry Dny komuny. Připomeňme, že obě Griegovy hry máme dostupné v českém překladu.

Inspiroval-li Griega Mejerchold s Vachtangovem, ovlivnil Jense Bjørneboa právě koncept Bertolta Brechta, jak se s ním seznámil za svého pobytu v Německu na konci 50. let prostřednictvím představení Berliner Ensemblu ve východním Berlíně. Bjørneboovu debutu ovšem předcházela i práce učitele na alternativní škole, v níž hrál divadlo se studenty, režijní práce v klasickém kamenném divadle i spolupráce s pozdějším zakladatelem Odin Teatret Eugeniem Barbou a přátelství s Marcelem Marceauem - díky těmto vlivům najdeme v jeho dramatice prvky pantomimy, cirkusu a dalšśho fyzického divadla. Formálně navazuje Bjørneboe ve svých raných hrách na Brechta v mnoha ohledech. Tematicky ho německý divadelník ovšem více než nudí. De Figueiredo prozkoumává trojici Bjørneboových her, z nichž dvě byly přeloženy i do češtiny (Milovníci ptactva a Semmelweis). Ačkoli hra z roku 1966 o ptactvamilovných Němcích, kteří se po válce rozhodnou zrrídit v jistém italském městečku agroturistický ráj a čekají, co to udělá s místními obyvateli, připomíná nejvíce tvorbu Friedricha Dürrenmatta, jde zde opět o Brechtovými postupy inspirovaný spektál s písněmi, pantomimou a vnořenými retrospektivními scénami, který kritizuje penězi korumpovatelnou společnost. Jak popisuje de Figueiredo, tato hra měla pozoruhodný dvojí život, protože Eugenio Barba na základě Bjørneboovy synopse napsal svou vlastní volnou verzi nazvanou $O r$ nitofilové, s níž v roce 1965 otevřel své právě založené Odin Teatret. Určité prvky z této verze nakonec pronikly i do Bjørneboovy konečné verze, kterou v roce 1966 uvedlo norské Národní divadlo v režii bývalého Brechtova spolupracovníka Carla Webera.

Čtenář zvědavý na to, jak se de Figueiredo vyrovnal s klasifikací záplavy současné norské dramatiky, musí konstatovat, že autor po svém zvyku nejprve pečlivě objasní kontext - odkud se současní 
dramatici vzali, jaká jsou jejich témata v Norsku napsáno, věcně shrne, propojí a jazyk, přičemž několik stránek věnuje s krátkými analýzami jejich her a dodá také „scénickým textům“ (jak bývá tato svou perspektivu, která se odvozuje od kategorie v Norsku nazývána) postdra- zvolené metody výzkumu.

matického divadla (Konkrétně v osobě Při své nedávné návštěvě České republibásníka Øyvinda Berga a jeho textů pro ky autor na adresu své nové knihy ironicky projektové divadlo Baktruppen. Byt zde podotknul, že je rád, že ji zde může predochází autor $\mathrm{k}$ závěru, že pro své těsné zentovat, ale že v Norsku ji nikdo nečte. propojení s divadelním artefaktem musí Knihu si obratem vypůjčili nezávisle na být studovány z divadelněvědných nikoli literárněvědných pozic.). Poté de Figueiredo představí nejstálejší „hráče na ledě“, aby se následně mohl odpíchnout $\mathrm{k}$ analýze díla nejvýraznějšś čtveřice, jež přibližně od minulé dekády požívá kanonický status. Do centra jeho pozornosti se tak dostávají Jon Fosse, Cecilie Løveidová, Finn Iunker a Arne Lygre. V portrétech těchto autorů naplno vynikne de Figueiredova schopnost pregnantně syntetizovat dostupný teoretický materiál. Většinu

toho, co o těchto dramaticích bylo kdy DOI: 10.5817/TY2016-1-20 sobě hned dva lidé - jednu dámu zajímalo, jak je reflektováno dramatické dílo autora, jehož prózy léta překládá do češtiny, druhá chtěla vědět, jak se kulturní klima radikálních 70. let projevilo v norské dramatice. Tento zájem budiž důkazem pravdy, že knihy tohoto typu nikdy nečte široký čtenářský okruh, jejich čtenáři si je ale vždycky najdou a jejich význam pro reflexi určité éry a fenoménu je naprosto zásadní a nezastupitelný. 